\title{
Article \\ The Protective Effect of Carotenoids, Polyphenols, and Estradiol on Dermal Fibroblasts under Oxidative Stress
}

\author{
Aya Darawsha, Aviram Trachtenberg (D), Joseph Levy ${ }^{\dagger}$ and Yoav Sharoni *(D) \\ Department of Clinical Biochemistry and Pharmacology, Faculty of Health Sciences, \\ Ben-Gurion University of the Negev, Beer Sheva 8410501, Israel; ayadar@post.bgu.ac.il (A.D.); \\ aviramtr@post.bgu.ac.il (A.T.) \\ * Correspondence: yoav@bgu.ac.il; Tel.: +972-52-4830883 \\ + Deceased.
}

check for updates

Citation: Darawsha, A.; Trachtenberg, A.; Levy, J.; Sharoni, Y. The Protective Effect of Carotenoids, Polyphenols, and Estradiol on Dermal Fibroblasts under Oxidative Stress. Antioxidants 2021, 10, 2023. https://doi.org/10.3390/ antiox10122023

Academic Editors: Soliman Khatib and Dana Atrahimovich Blatt

Received: 14 November 2021 Accepted: 18 December 2021 Published: 20 December 2021

Publisher's Note: MDPI stays neutral with regard to jurisdictional claims in published maps and institutional affiliations.

Copyright: (C) 2021 by the authors. Licensee MDPI, Basel, Switzerland. This article is an open access article distributed under the terms and conditions of the Creative Commons Attribution (CC BY) license (https:// creativecommons.org/licenses/by/ $4.0 /)$.

\begin{abstract}
Skin ageing is influenced by several factors including environmental exposure and hormonal changes. Reactive oxygen species (ROS), which mediate many of the effects of these factors, induce inflammatory processes in the skin and increase the production of matrix metalloproteinases (MMPs) in dermal fibroblasts, which leads to collagen degradation. Several studies have shown the protective role of estrogens and a diet rich in fruits and vegetables on skin physiology. Previous studies have shown that dietary carotenoids and polyphenols activate the cell's antioxidant defense system by increasing antioxidant response element/Nrf2 (ARE/Nrf2) transcriptional activity and reducing the inflammatory response. The aim of the current study was to examine the protective effect of such dietary-derived compounds and estradiol on dermal fibroblasts under oxidative stress induced by $\mathrm{H}_{2} \mathrm{O}_{2}$. Human dermal fibroblasts were used to study the effect of $\mathrm{H}_{2} \mathrm{O}_{2}$ on cell number and apoptosis, MMP-1, and pro-collagen secretion as markers of skin damage. Treatment of cells with $\mathrm{H}_{2} \mathrm{O}_{2}$ led to cell death, increased secretion of MMP-1, and decreased pro-collagen secretion. Pre-treatment with tomato and rosemary extracts, and with estradiol, reversed the effects of the oxidative stress. This was associated with a reduction in intracellular ROS levels, probably through the measured increased activity of ARE/Nrf2. Conclusions: This study indicates that carotenoids, polyphenols, and estradiol protect dermal fibroblasts from oxidative stress-induced damage through a reduction in ROS levels.
\end{abstract}

Keywords: lycopene; carnosic acid; apoptosis; matrix metalloproteinase (MMP); collagen; antioxidant response element/Nrf2 (ARE/Nrf2); reactive oxygen species (ROS); NHDF cells

\section{Introduction}

The skin is affected by environmental factors such as exposure to UV radiation, air pollutants, xenobiotics, and cigarette smoke [1,2], and by endogenous changes that occur with ageing [3]. These factors generally increase oxidative stress by generating reactive oxygen species (ROS) [1,2]. Oxidative stress, defined as a disturbance in the balance between the production of ROS and the antioxidant defenses [4], leads to changes in DNA, proteins, and lipids; and activation of inflammatory processes and signaling pathways that may cause various chronic and degenerative diseases [5], such as diabetes [4], cancer [6], neurological [7], and cardiovascular diseases [8]. Oxidative stress can also cause skin damage due to induction of apoptotic cell death [9,10]; activation of inflammatory processes [1]; an increase in metalloproteinases (MMPs), which degrade collagen in the extracellular matrix [11,12]; and a reduction in collagen production [13]. All of these changes accelerate skin ageing.

Epidemiological and clinical studies indicate that a diet rich in fruits and vegetables improves skin health [14], and that plant-derived compounds (phytonutrients) reduce oxidative stress-induced skin damage $[15,16]$. Among these active phytonutrients are 
carotenoids and polyphenols [16]. It was suggested that the protective effects of phytonutrients are mediated by the modulation of signaling pathways that are involved in the adverse effects of oxidative stress. This modulation includes reduction in the activities of the nuclear factor- $\mathrm{kB}$ (NF- $\mathrm{kB}$ ) transcription system, activator protein 1 (AP-1), and mitogen-activated protein kinase (MAPK) [17,18], and improving the antioxidant defense mechanism [19]. Several studies, including our own, suggest that modulation of these signaling pathways by phytonutrients can lead to a reduction in inflammatory processes [20-22] and MMP expression [17,23], and increase collagen synthesis [17].

Estradiol plays an important role in maintaining skin health [18], which is impaired in menopause due to a dramatic reduction in estradiol levels [18]. Treatment with estrogens (hormonal replacement therapy) increases collagen levels which improve skin elasticity [24]. These effects are partially associated with a reduction in oxidative stress [18] through increasing the expression of antioxidant enzymes and modulating the activity of the antioxidant response element/Nrf2 (ARE/Nrf2) transcription system [25]. Carotenoids were shown to activate the ARE/Nrf2 transcription system in several cell types [26], including keratinocytes [21], the main cell type of the skin epidermal layer. This system is also activated by polyphenols [21,27]. The activation of ARE/Nrf2 by carotenoids is probably exerted by carotenoid-oxidized derivatives which can be formed in the cells, but not by the intact molecules [28].

The aim of the current study was to investigate the effect of oxidative stress on primary human dermal fibroblasts and the ability of phytonutrients and estradiol to protect the cells from ROS-induced damage. These fibroblasts, which originate in the dermis layer of the skin, were used because they are the main source of collagen in the skin. Incubation with $\mathrm{H}_{2} \mathrm{O}_{2}$ was used to increase intracellular ROS. The effect of both $\mathrm{H}_{2} \mathrm{O}_{2}$ and the tested compounds (tomato and rosemary extracts and estradiol) was examined on cell death, MMP-1 and pro-collagen 1a1 secretions, and ROS level. The combined effect of $\mathrm{H}_{2} \mathrm{O}_{2}$ and the tested compounds on the activation of the ARE/Nrf2 transcription system was examined as a possible mechanism for the protection of dermal fibroblasts from oxidative stress.

\section{Materials and Methods}

\subsection{Materials}

Tomato extract $\left(\right.$ Lycomato $^{\mathrm{TM}}$ ) and rosemary extract were a gift of Lycored Ltd., Beer Sheva, Israel). The tomato extract, prepared by ethyl acetate extraction of tomato pulp, contained $6 \%$ lycopene, other tomato carotenoids (phytoene and phytofluene above $1 \%$, beta-carotene above $0.2 \%$ ), and additional fat-soluble tomato components such as natural tocopherols (above $1.5 \%$ ) and phytosterols (1.1-2.5\%). The remainder were triacylglycerols $(70-72 \%)$, monoacylglycerols (8-9\%), and phospholipids (7-8\%). The rosemary extract was prepared by extraction with $80 \%$ ethanol. Its composition was only partially determined to contain carnosic acid $(20.2 \%)$ and carnosol $(2.5 \%)$ as the main polyphenols. $17 \beta$-estradiol was purchased from Sigma-Aldrich (Rehovot, Israel). Carotenoids were dissolved in tetrahydrofuran (THF), solubilized in cell culture medium, and their final concentration was measured as described previously [28-30]. Rosemary extract and estradiol were dissolved in ethanol. $\mathrm{H}_{2} \mathrm{O}_{2} 30 \%$ and THF, containing $0.025 \%$ butylated hydroxytoluene as an antioxidant, were purchased from Sigma-Aldrich. Dulbecco's modified Eagle's medium (DMEM), dextran-coated charcoal-treated fetal bovine serum (DCC-FBS), Hanks' solution, and 1M HEPES buffer were purchased from Biological Industries (Beth Haemek, Israel).

\subsection{Cell Culture}

Normal human dermal fibroblasts (NHDF) were purchased from PromoCell GmbH (Heidelberg, Germany). The cells were grown in PromoCell fibroblast growth medium 2 , according to the manufacturer's instructions, in a humidified atmosphere at $37^{\circ} \mathrm{C}$ in $5 \% \mathrm{CO}_{2}$. Before each experiment, cells were depleted of steroid hormones by maintaining them for 3-5 days in phenol red-free DMEM supplemented with 10\% DCC-FBS (DMEM- 
DCC-FBS). This medium was used throughout all experiments because it does not contain steroid hormones or any other compound with estrogenic activity, such as phenol red.

\subsection{Determination of Cell Number, and Secretion of MMP-1 and Procollagen 1a1}

NHDF cells were seeded in 96-well plates at a density of $10^{4}$ cells / well in DMEM-DCCFBS medium. Twenty-four hours later, cells were pre-incubated with phytonutrients or estradiol for $24 \mathrm{~h}$. Vehicle-treated control cells were incubated with the relevant amounts of solvents used in a particular experiment, which had no effect on the measured parameters. The medium was then replaced with one containing the treatment compounds, with or without $\mathrm{H}_{2} \mathrm{O}_{2}$ and incubated for an additional $24 \mathrm{~h}$. Thereafter, medium was removed and frozen for the analysis of secreted proteins, and the cell number was determined by the XTT Cell Proliferation Kit (Biological Industries, Beth Haemek, Israel), according to the manufacturer's instructions. MMP-1 and pro-collagen 1a1 protein levels in cell culture supernatants were quantified by ELISA using the Human Total MMP-1 DuoSet and Human Pro-Collagen 1a1 DuoSet, ELISA kits (R\&D Systems, Inc., Minneapolis, MN, USA), according to the manufacturer's instructions. Optical density was measured using a VERSAmax tunable microplate reader (Molecular Devices, Menlo Park, CA, USA). Results of the cell number, MMP-1, and pro-collagen were calculated as a percent of the values obtained in control cells, treated with a vehicle without $\mathrm{H}_{2} \mathrm{O}_{2}$.

\subsection{Assessment of Apoptosis}

Cells were seeded in 6-well plates at $3 \times 10^{5}$ cells/well. Twenty-four hours later, they were pre-incubated with the phytonutrients or estradiol for $24 \mathrm{~h}$. The medium was then replaced with one containing the treatment compounds, with or without $\mathrm{H}_{2} \mathrm{O}_{2}$, and incubated for an additional $12 \mathrm{~h}$. Cells were washed in PBS and stained with Annexin V and 7-aminoactinomycin D (7-AAD), using the Annexin V-FITC/7-AAD Apoptosis Detection Kit (Biogems, Cat\# 62700-50, Chai Wan, Hong Kong), according to the manufacturer's protocol. The percentages of apoptotic cells were determined by flow cytometry on a Gallios instrument (Beckman Coulter Gallios Flow Cytometer, Brea, CA, USA). For each analysis, 10,000 events were recorded, and the data were processed using Kaluza software, version \#2.1, (Gallios ${ }^{\mathrm{TM}}$ Kaluza). As a positive control, cells were incubated with $1.25 \mu \mathrm{M}$ staurosporine for $18 \mathrm{~h}$ [31]. Annexin V positive/7AAD-negative cells were considered to be in the early apoptotic phase, and cells positive for both Annexin V and 7AAD were considered to be late apoptotic.

\subsection{Detection of Intracellular ROS}

Cells were seeded in 6-well plates at $3 \times 10^{5}$ cells/well. Twenty-four hours later, cells were pre-incubated with the phytonutrients or estradiol for $24 \mathrm{~h}$. The medium was then replaced with one containing the treatment compounds with or without $\mathrm{H}_{2} \mathrm{O}_{2}$ and incubated for an additional $90 \mathrm{~min}$. Intracellular ROS were detected by $2^{\prime}, 7^{\prime}$-dichlorofluorescin diacetate (DCFH-DA, Sigma-Aldrich) staining. Briefly, cells were trypsinized, and washed by Hanks' solution containing $10 \mathrm{mM}$ HEPES buffer, $\mathrm{pH}=7.4$, followed by cell staining with $5 \mu \mathrm{M}$ DCFH-DA for $30 \mathrm{~min}$ at $37^{\circ} \mathrm{C}$ in the dark. Cells were analyzed by flow cytometry using the Gallios instrument. Cells treated with $0.5 \mathrm{mM} \mathrm{H}_{2} \mathrm{O}_{2}$ for 15 min were used as a positive control. Untreated and unstained cells were used as a negative control.

\subsection{Transient Transfection and ARE/Nrf2 Reporter Gene Assay}

NHDF cells were seeded in 24 -well plates at $10^{5}$ cells/well. Twenty-four hours later, they were transfected using jetPEI reagent (Polyplus Transfection, Illkrich, France). Briefly, cells were rinsed once with serum-free medium, followed by the addition of $0.45 \mathrm{~mL}$ of medium and $50 \mu \mathrm{L}$ of a mixture containing DNA and jetPEI reagent at a charge ratio of 1:5. The total amount of DNA was $0.25 \mu \mathrm{g}$, containing $0.2 \mu \mathrm{g} 4 \mathrm{xARE}$ reporter construct [32] that was kindly provided by Dr. M. Hannink (University of Missouri-Columbia, Columbia, MO, USA) and $0.05 \mu \mathrm{g}$ Renilla luciferase (P-RL-null) expression vectors, which served as 
an internal transfection standard, and was purchased from Promega (Madison, WI, USA). These conditions were found to be optimal for the dermal fibroblasts. The cells were then incubated for $6 \mathrm{~h}$ at $37^{\circ} \mathrm{C}$. Next, the medium was replaced with DMEM-DCC-FBS plus the test compounds, and cells were incubated for an additional $16 \mathrm{~h}$. Cell extracts were prepared for luciferase reporter assay (Dual Luciferase Reporter Assay System, Promega) according to the manufacturer's instructions, and luminescence was determined using a Turner Biosystems luminometer (Sunnyvale, CA, USA).

\subsection{Statistical Analysis}

All experiments were performed in triplicate or duplicate and repeated two to seven times as indicated in the figure legends. Statistically significant differences between two experimental groups were determined using one-way ANOVA with Dunnett's multiple comparison post-hoc analysis. Data are presented as the mean \pm SEM. $p<0.05$ was considered statistically significant. The statistical analyses were performed using GraphPad Prism 6.0 software (Graph-Pad Software, San Diego, CA, USA).

\section{Results}

3.1. $\mathrm{H}_{2} \mathrm{O}_{2}$ Induces Cell Death of Dermal Fibroblasts, Increases MMP-1 Secretion, and Decreases Pro-Collagen 1a1

Oxidative stress in human primary dermal fibroblasts was induced by incubating the cells with increasing concentrations of $\mathrm{H}_{2} \mathrm{O}_{2}(0-75 \mu \mathrm{M})$ for $24 \mathrm{~h}$. The cell number, checked by the XTT method, decreased by $\mathrm{H}_{2} \mathrm{O}_{2}$ dose-dependently. At $50 \mu \mathrm{M}$, only about $20 \%$ of the cells were viable, and at higher concentrations, almost all cells died (Figure 1a). MMP-1 and pro-collagen 1a1 secretion were measured in the media using specific ELISA assays. $\mathrm{H}_{2} \mathrm{O}_{2}$ increased MMP-1 secretion and decreased pro-collagen 1a1 secretion (Figure 1b). These effects of $\mathrm{H}_{2} \mathrm{O}_{2}$ in dermal fibroblasts, cell death, and the inverse changes in MMP- 1 and pro-collagen secretion may cause thinning of the dermis and a reduction in skin elasticity.

(a)

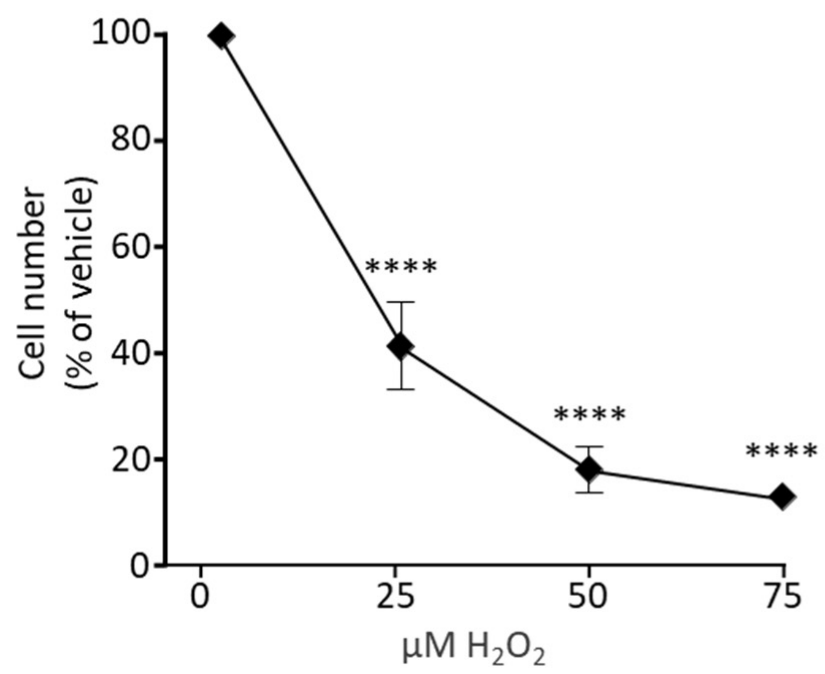

(b)

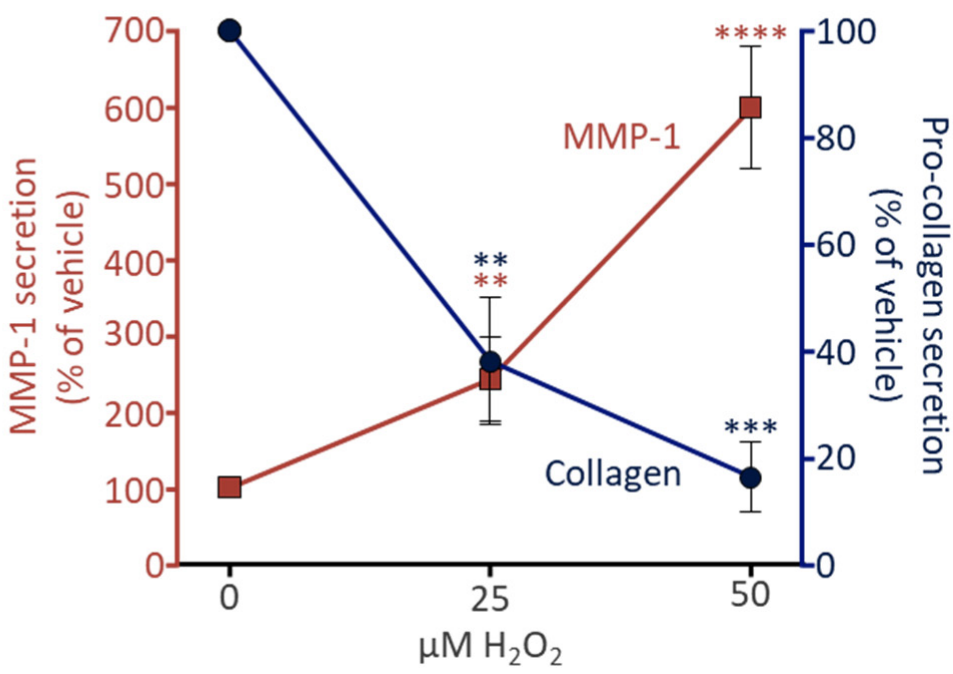

Figure 1. NHDF cells were seeded in 96-well plates ( $10^{4}$ cells/well). Twenty-four hours later, the cells were incubated with the indicated concentrations of $\mathrm{H}_{2} \mathrm{O}_{2}$ for $24 \mathrm{~h}$. (a) The cell number was determined by the XTT method as described in Section 2.3. (b) Secretion of MMP-1 and pro-collagen 1a1 were determined in the media using ELISA assays as described in Section 2.3. Results are presented as a percent of the values without $\mathrm{H}_{2} \mathrm{O}_{2}$. Y-axis scales: $100 \%$ of the cell number was $35,534 \pm 1251$ cells/well; $100 \%$ of the MMP-1 secretion was $47 \pm 12$ pmol per 1000 cells; $100 \%$ of the pro-collagen secretion was $107 \pm 60$ pmol per 1000 cells. Values are the means \pm SEM of 3-5 experiments, each performed in triplicate. ${ }^{* *} p<0.01$, *** $p<0.001$, **** $p<0.0001$, significant difference between the vehicle with and without $\mathrm{H}_{2} \mathrm{O}_{2}$. 


\subsection{The Phytonutrients of Tomato and Rosemary Extracts and the Hormone Estradiol Protect} Fibroblasts from $\mathrm{H}_{2} \mathrm{O}_{2}$-Induced Cell Damage

To investigate whether phytonutrients can protect NHDF cells from $\mathrm{H}_{2} \mathrm{O}_{2}$-induced damage, cells were pre-incubated for $24 \mathrm{~h}$ with increasing concentrations of tomato or rosemary extracts before exposing them to $\mathrm{H}_{2} \mathrm{O}_{2}$ for an additional $24 \mathrm{~h}$ in the presence of the phytonutrients. Partial protection from cell death was evident at most tested concentrations of the extracts (Figure 2a,b); however, these effects were not significant. Nonetheless, large and significant effects were obtained in the secretion of MMP-1 and pro-collagen, and both tomato and rosemary extracts reversed the effects of $\mathrm{H}_{2} \mathrm{O}_{2}$. Tomato extract reduced the $\mathrm{H}_{2} \mathrm{O}_{2}$-induced rise in MMP- 1 secretion by about $50 \%$ (Figure $2 \mathrm{c}$ ) and completely restored pro-collagen secretion (Figure 2e). Similarly, rosemary extract decreased MMP-1 secretion (Figure 2d) and increased pro-collagen secretion (Figure 2f) to their basal levels.
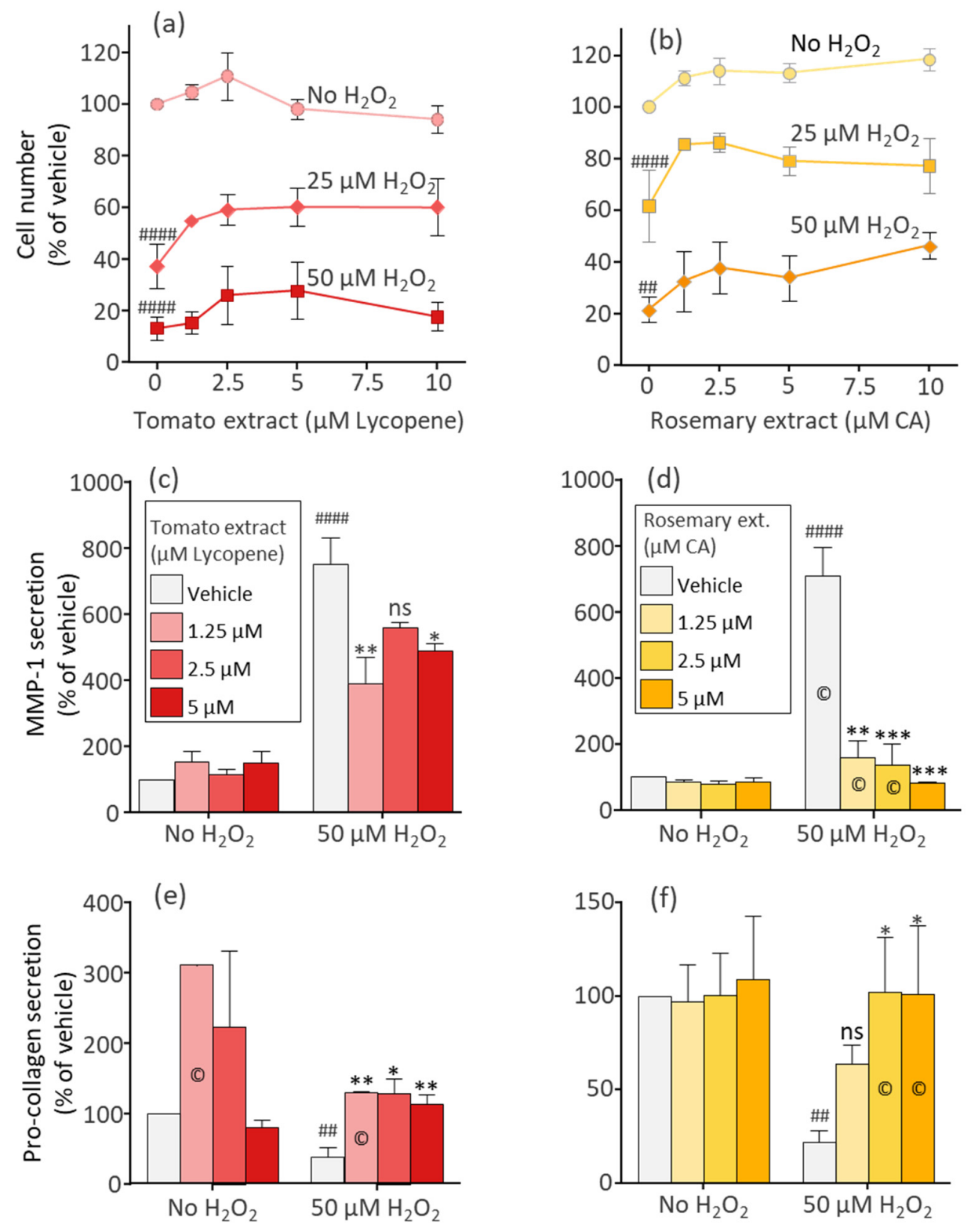

Figure 2. Tomato and rosemary extracts protect fibroblasts from $\mathrm{H}_{2} \mathrm{O}_{2}$-induced cell damage. NHDF cells were pre-incubated for $24 \mathrm{~h}$ with tomato extract or rosemary extract at the indicated concentrations of lycopene or carnosic acid, respectively. Then, $\mathrm{H}_{2} \mathrm{O}_{2}$ was added at the indicated concentrations for an additional $24 \mathrm{~h}$. The cell number $(\mathbf{a}, \mathbf{b})$, and secretion of MMP-1 (c,d) and pro-collagen 1a1 (e,f), 
were determined as described in Figure 1. Results are presented as a percent of the values without $\mathrm{H}_{2} \mathrm{O}_{2}$. Y-axis scales: $100 \%$ of the cell number was $36,609 \pm 2029$ cells/well; $100 \%$ of the MMP-1 secretion was $110 \pm 37$ pmol per 1000 cells; $100 \%$ of the pro-collagen secretion was $112 \pm 50$ pmol per 1000 cells. Values are the means \pm SEM of 2-7 experiments, each performed in triplicate. The experimental groups that were repeated in only two experiments are marked with the symbol @ in the center of the relevant column. \#\# $p<0.01$, \#\#\#\# $p<0.0001$, significant difference between the vehicle with and without $\mathrm{H}_{2} \mathrm{O}_{2} \cdot{ }^{*} p<0.005,{ }^{* *} p<0.01,{ }^{* * *} p<0.001$ ), significant difference between the vehicle and other treatments in the presence of $\mathrm{H}_{2} \mathrm{O}_{2}$ (ns-non-significant).

Although the protection from oxidative stress-induced damage by the tomato and rosemary extracts was significant, it was examined whether more protection can be achieved by their combination. Indeed, the combination of rosemary extract with tomato extract resulted in better protection of the cells compared to each compound alone (Figure 3). The effect of the combination on the cell number was not significantly different from the single compounds (Figure 3a); however, in these experiments, a significant reduction in MMP-1 secretion was evident only when the cells were treated with the phytonutrient combination (Figure $3 b$ ). Although the effect of single phytonutrients on pro-collagen secretion was significant, treatment with their combination induced a significantly larger increase compared to each compound alone (Figure 3c). The treatment of cells under oxidative stress, with the combination of tomato and rosemary extracts, resulted in a pro-collagen level that was higher than the basal level without $\mathrm{H}_{2} \mathrm{O}_{2}$.

The protective effect of estradiol on cell survival was stronger than the effect of the phytonutrients, and in the presence of $10 \mathrm{nM}$ estradiol, the cells were completely resistant to cell death induced by $25 \mu \mathrm{M} \mathrm{H}_{2} \mathrm{O}_{2}$ (Figure 4a). Similar to the effects of the phytonutrients, estradiol decreased MMP-1 secretion (Figure $4 \mathrm{~b}$ ) and increased pro-collagen secretion back to basal levels without $\mathrm{H}_{2} \mathrm{O}_{2}$ (Figure 4c).

\subsection{Tomato Extract, Rosemary Extract, and Estradiol Protect Dermal Fibroblasts from $\mathrm{H}_{2} \mathrm{O}_{2}$-Induced Apoptosis}

It was demonstrated above that phytonutrients and estradiol protect dermal fibroblasts from $\mathrm{H}_{2} \mathrm{O}_{2}$-induced cell death. Consequently, it was examined whether $\mathrm{H}_{2} \mathrm{O}_{2}$ induced apoptosis and whether the tested compounds protected against this route of cell death. Using flow cytometry and Annexin-V/7AAD staining, it was found that $\mathrm{H}_{2} \mathrm{O}_{2}$ causes apoptotic cell death (Figure 5). The typical flow cytometric data of one experiment with estradiol is shown in Figure 5a. Only about 1\% of cells were apoptotic when the cells were treated with the vehicle, with or without estradiol (almost all the cells appear in the unstained lower left square). After $12 \mathrm{~h}$ with $\mathrm{H}_{2} \mathrm{O}_{2}, 10 \%$ of the cells were in an early apoptotic state (lower right panel), and $81 \%$ were in late apoptosis (upper right square). Pre-incubation with $10 \mathrm{nM}$ estradiol resulted in a reduction to $8 \%$ and $44 \%$ of early- and late-apoptotic cells, respectively. The average total apoptosis (early + late) which was negligible in the control cells, increased after $\mathrm{H}_{2} \mathrm{O}_{2}$ treatment to more than $90 \%$ (Figure $5 \mathrm{~b}$ ). Estradiol and the phytonutrients reduced total apoptosis to less than $30 \%$. 


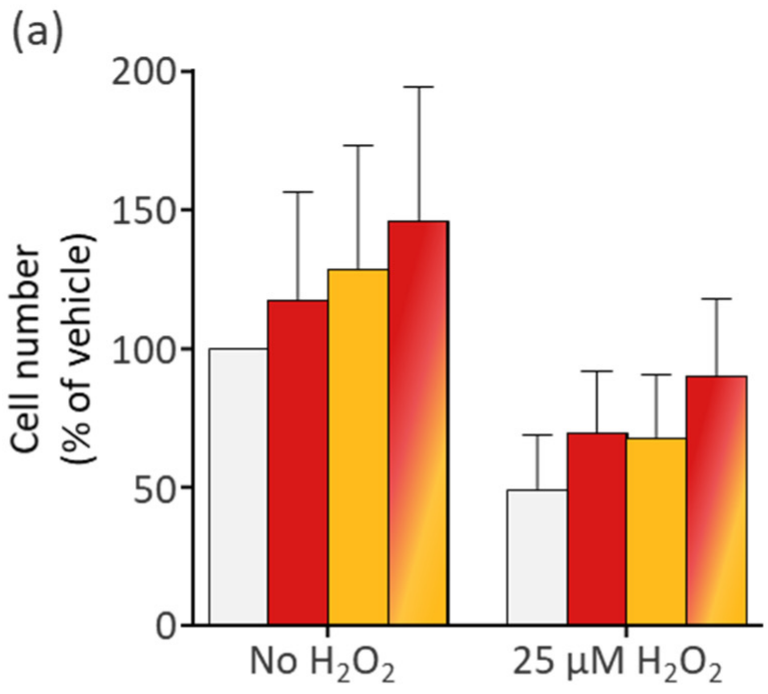

\section{$\square$ Vehicle $\square$ Tomato extract $\square$ Rosemary extract $\square$ Tomato extract + Rosemary extract}

(b)

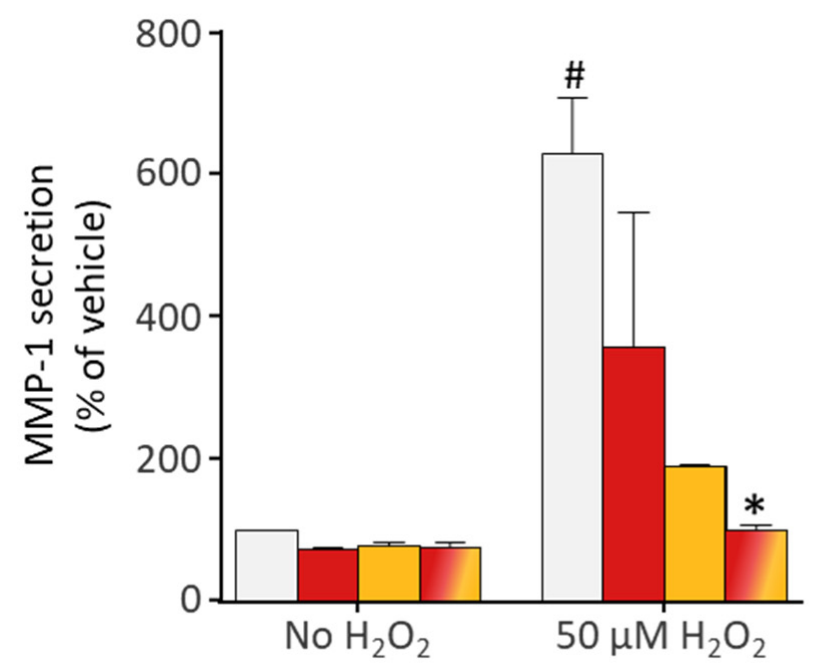

(c)

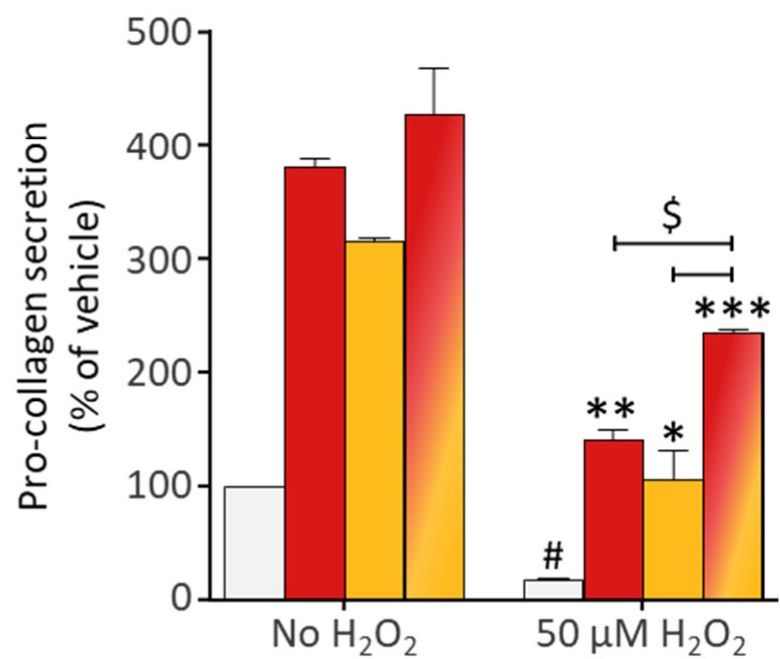

Figure 3. Protection from $\mathrm{H}_{2} \mathrm{O}_{2}$-induced cell damage was improved by a combination of tomato and rosemary extracts. NHDF cells were pre-incubated for $24 \mathrm{~h}$ with tomato extract $(2.5 \mu \mathrm{M}$ lycopene), rosemary extract $(2.5 \mu \mathrm{M}$ carnosic acid), or their combination. Then, $\mathrm{H}_{2} \mathrm{O}_{2}$ was added at the indicated concentrations for an additional $24 \mathrm{~h}$. The cell number (a), and secretion of MMP-1 (b) and pro-collagen 1a1 (c), were determined as described in the legend of Figure 1. Results are presented as a percent of the values without $\mathrm{H}_{2} \mathrm{O}_{2}$. Y-axis scales: $100 \%$ of cell number was $8067 \pm 6141$ cells/well; $100 \%$ of the MMP-1 secretion was $84 \pm 5$ pmol per 1000 cells; $100 \%$ of the pro-collagen secretion was $16.5 \pm 0.5$, much lower than other experiments' pmol per 1000 cells. Values are the means \pm SD of 2-3 experiments, each performed in triplicate. $\#, p<0.05$, significant difference between the vehicle with and without $\mathrm{H}_{2} \mathrm{O}_{2} \cdot{ }^{*} p<0.005,{ }^{* *} p<0.01,{ }^{* * *} p<0.001$ ), significant difference between the vehicle and other treatments in the presence of $\mathrm{H}_{2} \mathrm{O}_{2} . \S, p<0.05$, between the combination and individual phytonutrients. 
(a)

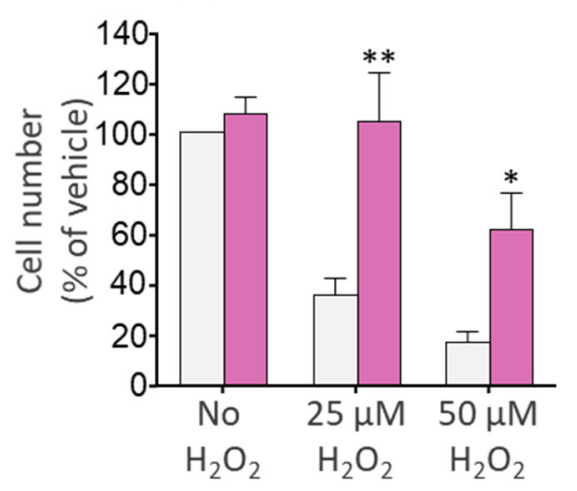

(b)

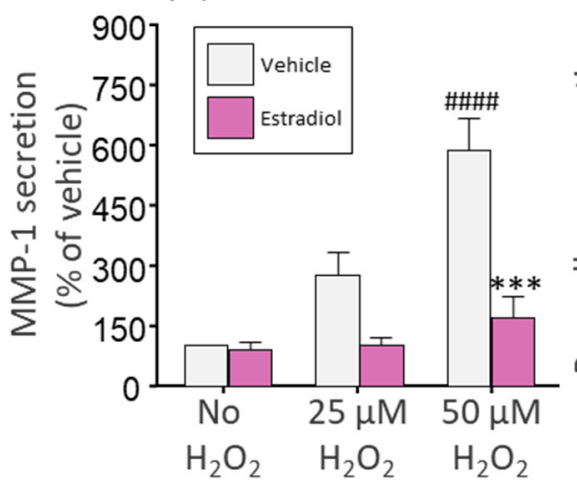

(c)

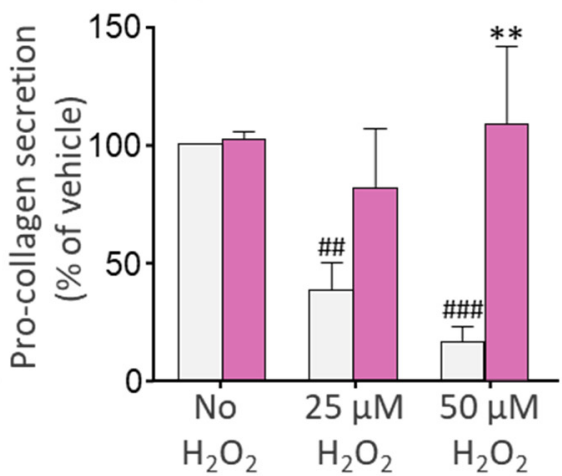

Figure 4. Estradiol protects fibroblasts from $\mathrm{H}_{2} \mathrm{O}_{2}$-induced cell damage. NHDF cells were pre-incubated for $24 \mathrm{~h}$ with $10 \mathrm{nM}$ estradiol. Then, $\mathrm{H}_{2} \mathrm{O}_{2}$ was added at the indicated concentrations for an additional $24 \mathrm{~h}$. The cell number $(\mathbf{a})$, and secretion of MMP-1 (b) and pro-collagen 1a1 (c), were determined as described in the legend of Figure 1. Results are presented as a percent of the values without $\mathrm{H}_{2} \mathrm{O}_{2}$. Y-axis scales: $100 \%$ of the cell number was $40,040 \pm 3011$ cells/well; $100 \%$ of the MMP-1 secretion was $54.3 \pm 7.6 \mathrm{pmol}$ per 1000 cells; $100 \%$ of the pro-collagen secretion was $32.7 \pm 16.7$ pmol per 1000 cells. Values are the means \pm SD of $2-7$ experiments, each performed in triplicate. \#\# $p<0.01$, \#\#\# $p<0.001$, \#\#\# $p<0.0001$, significant difference between the vehicle with and without $\mathrm{H}_{2} \mathrm{O}_{2} .{ }^{*} p<0.05$, ${ }^{* *} p<0.01$, ${ }^{* * *} p<0.001$, significant difference between the vehicle and other treatments in the presence of $\mathrm{H}_{2} \mathrm{O}_{2}$.

(a)

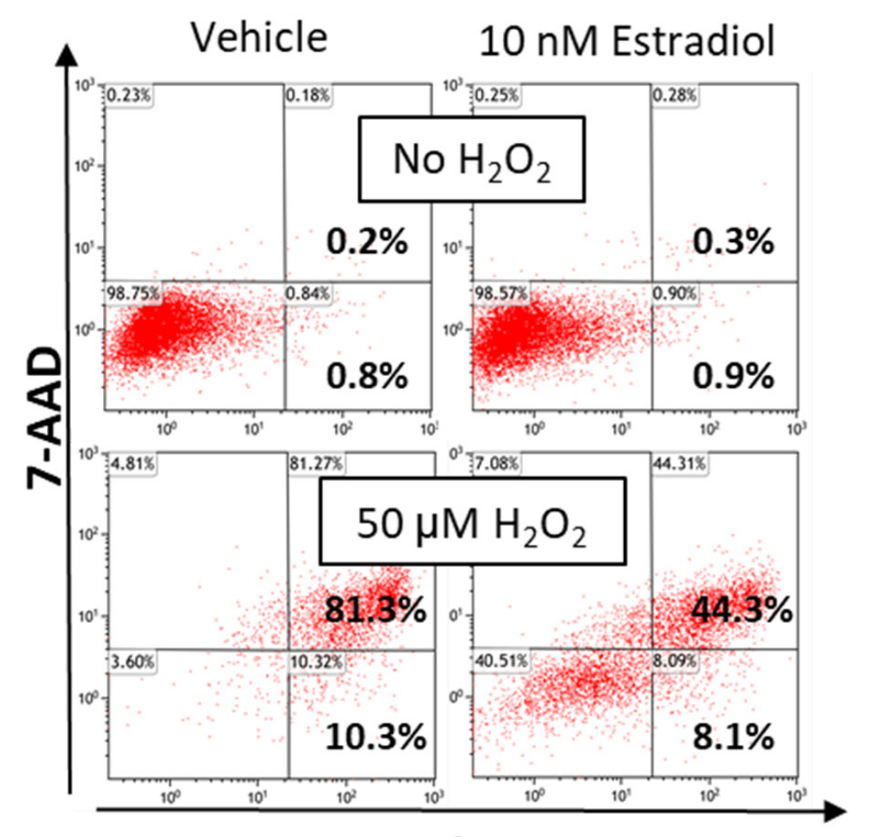

Annexin V-APC
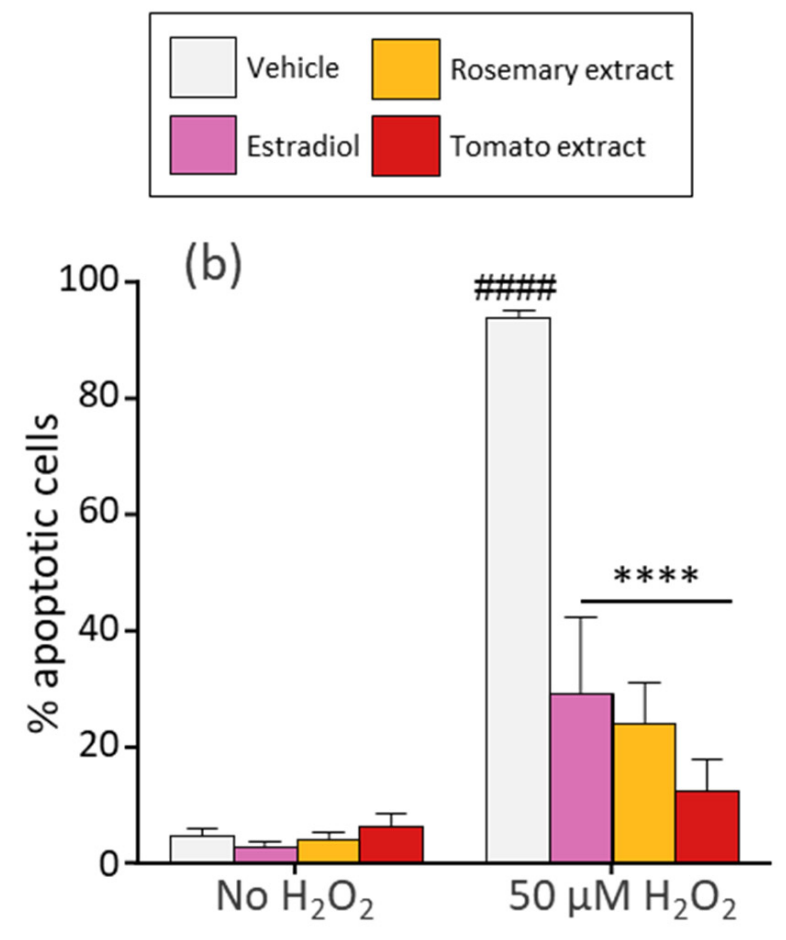

Figure 5. Estradiol and tomato and rosemary extracts protect fibroblasts against $\mathrm{H}_{2} \mathrm{O}_{2}$-induced apoptotic cell death. Cells were seeded in 6-well plates $\left(3 \times 10^{5}\right.$ cells / well) and were pre-incubated for $24 \mathrm{~h}$ with estradiol $(10 \mathrm{nM})$, rosemary extract ( $5 \mu \mathrm{M}$ carnosic acid), or tomato extract $\left(10 \mu \mathrm{M}\right.$ lycopene). Then, $\mathrm{H}_{2} \mathrm{O}_{2}(50 \mu \mathrm{M})$ was added for an additional $12 \mathrm{~h}$, and cell apoptosis was determined by flow cytometry as described in Section 2.4. (a) Typical flow cytometric data of Annexin-V and 7-AAD fluorescence, obtained in a representative experiment. (b) Averaged Annexin-V-stained cells (total = early + late apoptosis). Values (\% apoptotic cells) are the means \pm SEM of four experiments, each performed in duplicate. \#\#\#, $p<0.0001$, significant difference between the vehicle with and without $\mathrm{H}_{2} \mathrm{O}_{2} \cdot{ }^{* * * *}, p<0.0001$, significant difference between the vehicle and other treatments in the presence of $\mathrm{H}_{2} \mathrm{O}_{2}$. 


\subsection{Pre-Treatment of Dermal Fibroblasts with Tomato Extract, Rosemary Extract, and Estradiol} Reduces ROS Generated by $\mathrm{H}_{2} \mathrm{O}_{2}$

To verify that fibroblast cell damage was associated with oxidative stress, the cytoplasmic ROS level was determined by flow cytometry using a DCFH probe. Cells that were treated with $\mathrm{H}_{2} \mathrm{O}_{2}$ for 90 min showed a large increase in DCF fluorescence (Figure 6a, red tracing). The average geometric means of fluorescence intensities (MFI), indicating average ROS levels, increased by about six-fold (Figure 6c). Pre-incubation with estradiol (Figure 6a, black tracing) resulted in a tracing similar to the control (green tracing). ROS levels, as indicated by the MFI values, were reduced by estradiol, and the tomato and rosemary extracts back to basal level (Figure 6c). In a preliminary experiment, it was found that a reduction in ROS also occurred when the protective agents were added only during the pre-incubation, but not together with $\mathrm{H}_{2} \mathrm{O}_{2}$ (data not shown). This suggests that pre-incubation is required in order to reduce the ROS level. Indeed, when estradiol or the phytonutrients were added to cells at the same time as $\mathrm{H}_{2} \mathrm{O}_{2}$ without pre-incubation, there was no reduction in ROS levels (Figure $6 \mathrm{~d}$ and the black tracing in Figure $6 \mathrm{~b}$ ). These results indicate that pre-incubation of the fibroblasts with the phytonutrients and estradiol is necessary to reduce these levels, and that the reduction in the ROS level did not occur by a chemical scavenging reaction between the protective agents and ROS. The increase in ROS levels by $\mathrm{H}_{2} \mathrm{O}_{2}$ and their reduction by the phytonutrients and estradiol was associated with cell damage and its attenuation, respectively. Thus, it was tested whether, without pre-incubation, cells can be rescued from ROS-induced death. However, when the phytonutrients or estradiol were added at the same time as $\mathrm{H}_{2} \mathrm{O}_{2}$, the cell number remained low and was the same as that without the protecting compounds (Figure 6e).

\subsection{Oxidative Stress Increases the Induction of the ARE/Nrf2 Transcription System by the Phytonutrients and Estradiol}

The results in the previous section suggest that pre-incubation with the phytonutrients and estradiol is required to decrease ROS levels and protect fibroblasts from $\mathrm{H}_{2} \mathrm{O}_{2}$-induced adverse effects. This implies that during pre-incubation, the cells increased their antioxidant defense capacity. One probable explanation for this increased capacity is the induction of the ARE/Nrf2 transcription system, which induces the transcription of antioxidant enzymes and is known to be activated by the tested compounds. The ARE/Nrf2 transcriptional activity was determined by a reporter gene assay. As expected, this transcription system was activated by rosemary extract (Figure 7a), tomato extract (Figure $7 \mathrm{~b}$ ), and estradiol (Figure 7c) from two- to four-fold in the absence of $\mathrm{H}_{2} \mathrm{O}_{2} \cdot \mathrm{H}_{2} \mathrm{O}_{2}$ alone slightly increased this activity by two- to three-fold. In the presence of $\mathrm{H}_{2} \mathrm{O}_{2}$, the activation by the phytonutrients and estradiol was significantly higher than that of the compounds or $\mathrm{H}_{2} \mathrm{O}_{2}$ alone. 

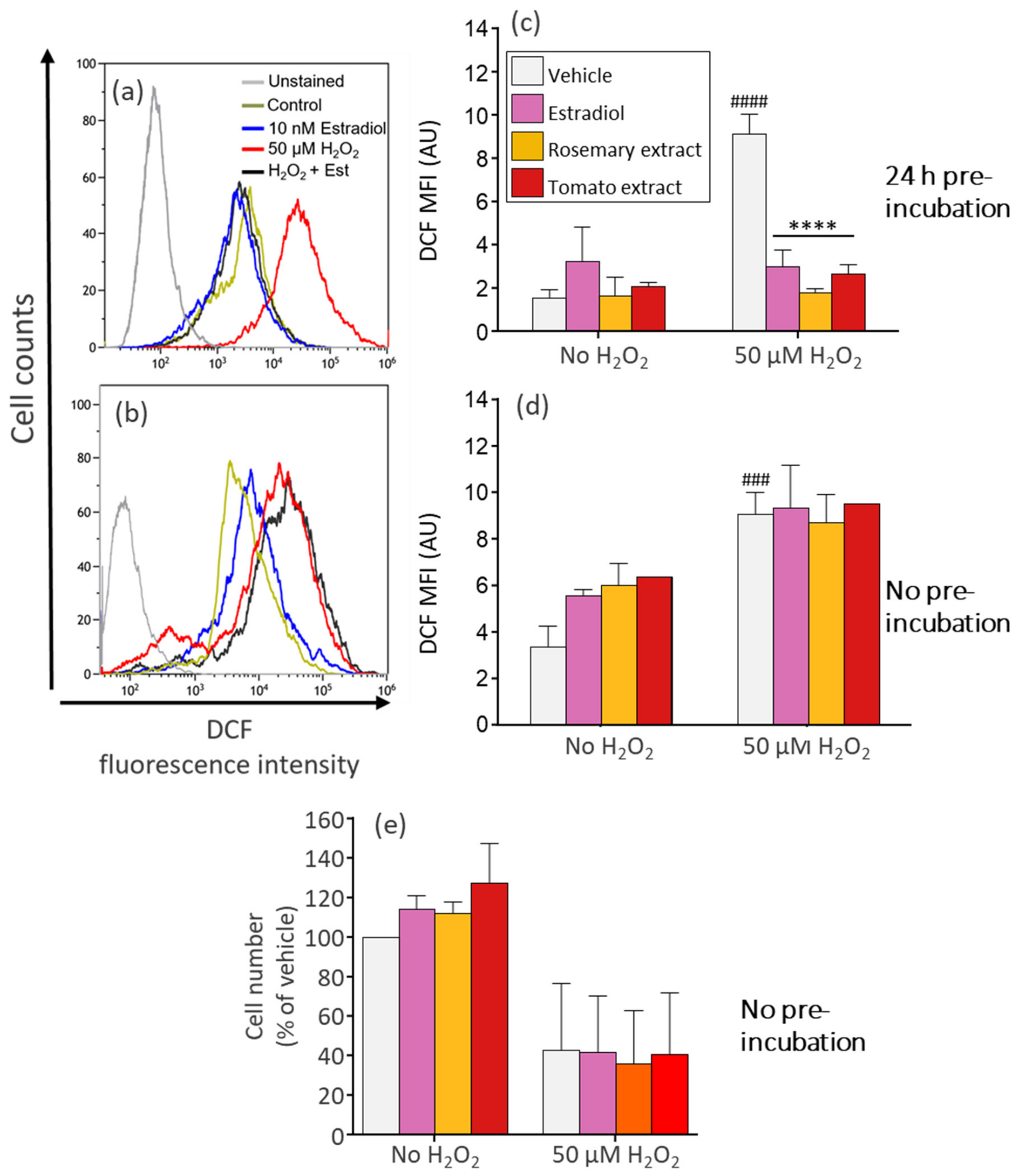

Figure 6. Pre-incubation with the phytonutrients or estradiol is required to reduce $\mathrm{H}_{2} \mathrm{O}_{2}$-generated ROS. Cells were seeded in 6-well plates $\left(3 \times 10^{5}\right.$ cells / well) and were pre-incubated for $24 \mathrm{~h}$ with $(\mathbf{a}, \mathbf{c})$ or without $(\mathbf{b}, \mathbf{d}, \mathbf{e})$ estradiol $(10 \mathrm{nM})$, rosemary extract ( $5 \mu \mathrm{M}$ carnosic acid), or tomato extract ( $10 \mu \mathrm{M}$ lycopene). Then, $\mathrm{H}_{2} \mathrm{O}_{2}(50 \mu \mathrm{M})$ was added together with the treatment compounds, and ROS levels (after $90 \mathrm{~min}$, a-d) or cell number (after $24 \mathrm{~h}$, e) were determined as described in Sections 2.3 and 2.5, respectively. (a,b) Typical flow cytometric histograms of DCF fluorescence obtained in a representative experiment with (a) or without $(\mathbf{b})$ pre-incubation. (c,d) Averaged geometric means of DCF fluorescence intensities (MFI) with (c) or without (d) pre-incubation. (e) Cell numbers without pre-incubation, $100 \%$ of the cell number was $37,858 \pm 676$ cells/well. Values are the means \pm SEM of $2-4$ experiments, each performed in duplicate. \#\#\# $p<0.001$, \#\#\# $p<0.0001$, significant difference between the vehicle with and without $\mathrm{H}_{2} \mathrm{O}_{2} \cdot{ }^{* * * *}, p<0.0001$, significant difference between the vehicle and other treatments in the presence of $\mathrm{H}_{2} \mathrm{O}_{2}$. 
(a)

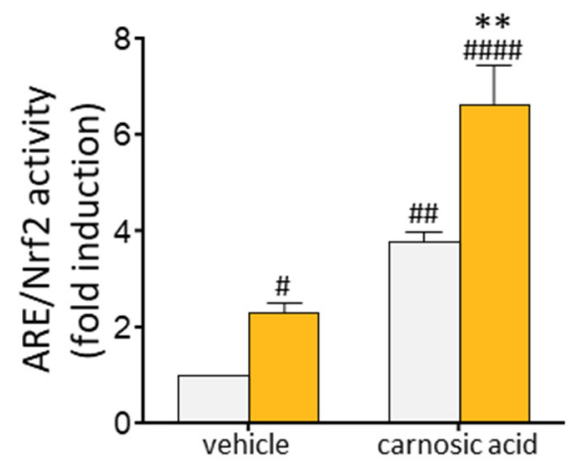

(b)

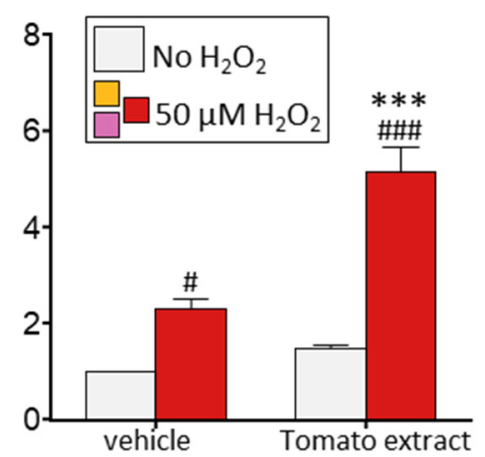

(c)

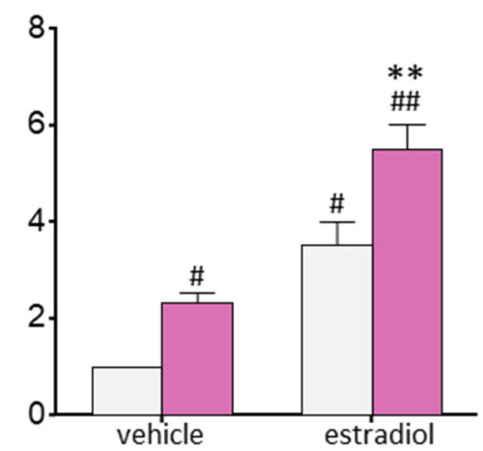

Figure 7. Activation of ARE/Nrf2 by the phytonutrients and estradiol in the presence of $\mathrm{H}_{2} \mathrm{O}_{2}$. Cells were seeded in 24-well plates ( $10^{5}$ cells/well), and $24 \mathrm{~h}$ later were transfected with the ARE/Nrf2 reporter gene, and ARE/Nrf2 transcriptional activity was determined as described in Section 2.6. After transfection, cells were incubated for $16 \mathrm{~h}$ with (a) rosemary extract (5 $\mu \mathrm{M}$ carnosic acid), (b) tomato extract (10 $\mu \mathrm{M}$ lycopene), or (c) estradiol (10 $\mathrm{nM}$ ), and with (dark columns) or without (light columns) $\mathrm{H}_{2} \mathrm{O}_{2}$. Values (fold induction) are the means \pm SEM of 3-4 experiments, each performed in triplicate. $\# p<0.05$, \#\# $p<0.01$, \#\#\# $p<0.001$, \#\#\#\# $p<0.0001$, significant difference between treatment and the vehicle without $\mathrm{H}_{2} \mathrm{O}_{2}$. ${ }^{* *} p<0.01,{ }^{* * *} p<0.001$, significant difference between treatments with and without $\mathrm{H}_{2} \mathrm{O}_{2}$.

\section{Discussion}

The current study suggests that dietary and hormonal supplementation can prevent oxidative stress-induced damage to dermal fibroblasts. The inhibition of dermal fibroblasts cell death and the reversal of oxidative stress-induced increase in MMP-1 secretion and reduction in pro-collagen levels, that were demonstrated here, suggest that ingestion or topical application of these and similar compounds can prevent oxidative stress-induced reduction in skin depth and elasticity. The protection of dermal fibroblasts by carotenoids, polyphenols, and estradiol shown in the current study may be relevant to skin damage that is caused by several factors such as UV radiation and environmental pollutants, inducing the generation of ROS [2] (Scheme 1). In this study, the dietary carotenoids, polyphenols, and estradiol reduced oxidative stress-induced apoptosis of dermal fibroblasts, reduced MMP-1 secretion, and increased pro-collagen levels. Previous studies have shown the induction of apoptosis by oxidative stress in keratinocytes [33] and fibroblast [10] skin cells. Carotenoids, including lutein [34] and astaxanthin [35], were shown to increase the keratinocyte cell number by reducing UV-induced apoptotic cell death. An in vivo study showed that the topical application of lycopene was capable of suppressing a UVBinduced cascade of apoptosis, as indicated by the reduced expression of caspase- 3 in murine skin [36]. Moreover, the protective role of polyphenols in skin cells has been shown in several studies. The survival of human dermal fibroblasts under $\mathrm{H}_{2} \mathrm{O}_{2}$-induced oxidative stress was increased by strawberry extract [37]. Various dietary polyphenols, including rosemary extract, were shown to increase keratinocyte cell survival after UVB irradiation [38-41]. Apoptosis inhibition was evident in most of these studies [38,39,41], and one compound, delphinidin, found in pomegranates, berries, and other pigmented fruits and vegetables, was also shown to inhibit apoptosis in mice skin [38]. 


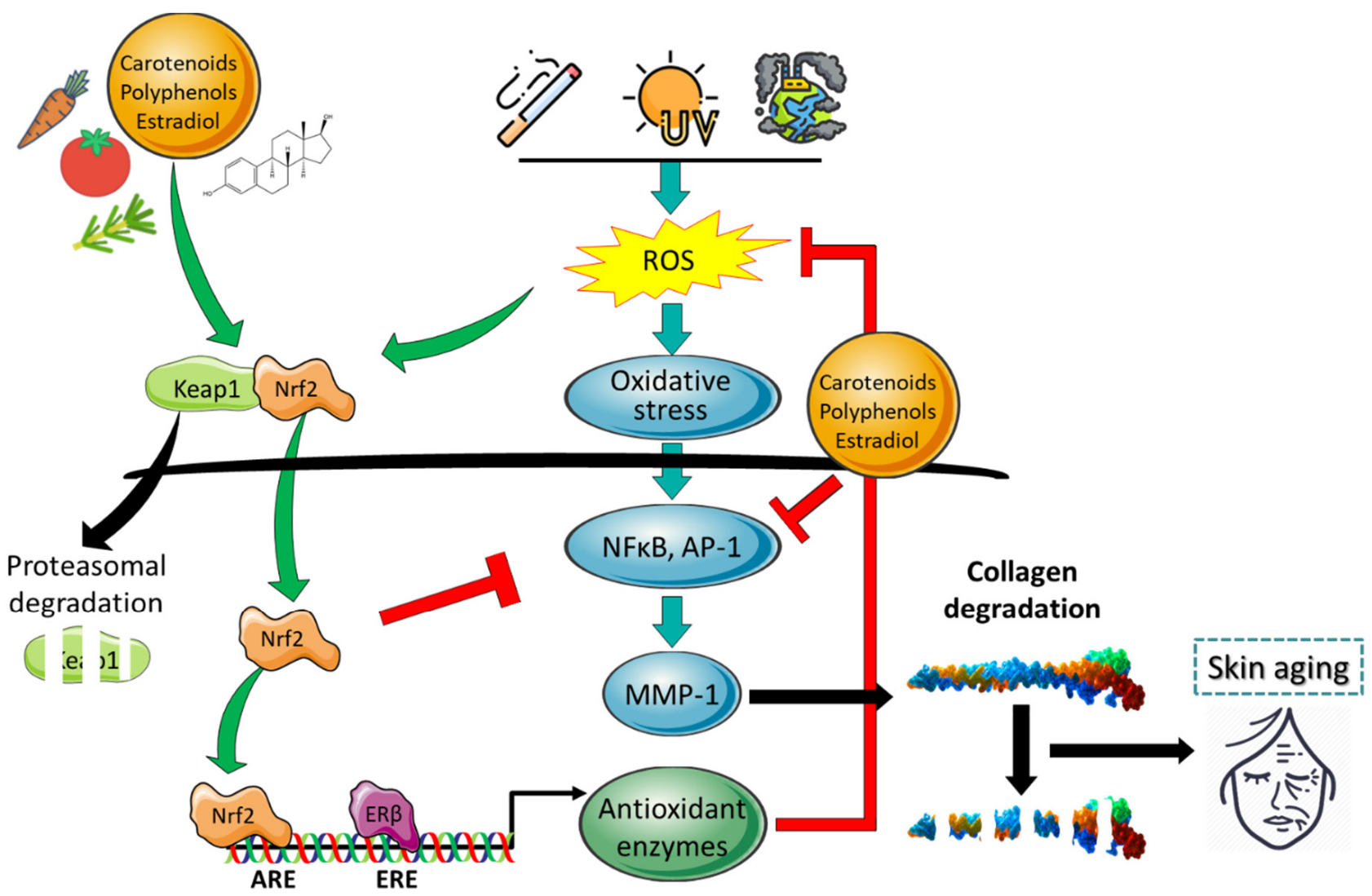

Scheme 1. A model summarizing the suggested effects of phytonutrients and estradiol on the parameters studied in dermal fibroblasts under oxidative stress. Increased cellular ROS is caused by several factors (e.g., UVB, air pollution, and smoking). Oxidative stress activates the NFKB and AP-1 transcription systems, which increases MMP-1 secretion and collagen degradation and decreases collagen secretion, leading to skin damage and aging. As a feedback mechanism, ROS activates the Nrf2 transcription system, which increases the expression of antioxidant enzymes that reduce ROS. ARE/Nrf2 is also induced by carotenoids, polyphenols, and estradiol. In addition, the expression of antioxidant enzymes can also be upregulated by estrogen receptor binding to an estrogen response element within the promoter region of the antioxidant enzyme. Carotenoids, polyphenols, and estradiol also inhibit NFKB and AP-1 activities, leading to a reversal of ROS damaging effects, delaying skin ageing.

In the skin extracellular matrix, similar to other tissues, there is a balance between the synthesis of new pro-collagen and the degradation of matrix collagen. This balance is disrupted by oxidative stress, which causes an increase in the production of MMPs [11,12,42] and a reduction in pro-collagen expression [11,13] (Scheme 1). Thus, the larger amount of pro-collagen attained by phytonutrient and estradiol treatments, and the reduced level of MMP-1, can restore this balance and, thus, improve skin elasticity. Previous studies have shown that polyphenols reduce MMP expression, both in vivo [43] and in vitro [17]. A similar reduction in MMP expression was shown by carotenoids in dermal fibroblasts [44] and in human skin $[45,46]$. Topical estradiol treatment reduced MMP-1 levels and increased pro-collagen expression in human skin [47], with similar effects found in murine bones [48]. Several signaling pathways are involved in the mechanism of oxidative stress-induced changes in MMP and collagen. A number of studies have shown that ROS induces the activation of MAPKs, which activate the NFkB and AP-1 transcription systems, leading to the increased expression of pro-inflammatory genes and MMPs [49-51]. Thus, inhibition of MAPKs, NFKB, and AP-1 by phytonutrients [49] may be the mechanism for reducing MMP-1 by the phytonutrients and estradiol in the current study (Scheme 1). A study from our laboratory showed that carotenoid derivatives inhibit NFKB and suggested a molecular mechanism for this inhibition [52]. $\beta$-carotene was found to inhibit NFkB in cancer cells [53], and lutein inhibited this transcription system in various cells of the choroid 
complex of the eye, both in vivo and in vitro [54]. The polyphenol, resveratrol, inhibited NFKB activity in mouse skin by blocking I $\mathrm{B}$ kinase activity [55], and a study from our laboratory demonstrated inhibition of UVB-induced NFKB activity by several carotenoids and polyphenols in human keratinocytes [21]. Estradiol was also shown to inhibit NFKB activity by increasing the expression of $I \kappa B \alpha$, the inhibitor of $N F \kappa B$ [56].

The protective effects of the tested compounds in the current study were associated with a marked reduction in ROS levels only when the cells were pre-incubated with the compounds before adding $\mathrm{H}_{2} \mathrm{O}_{2}$. Thus, as discussed in Section 3.5, antioxidant defense was indeed improved during the pre-incubation, and this was possibly achieved by increased transcriptional activity of ARE/Nrf2, which can increase the expression of antioxidant enzymes, which can lead to ROS reduction (Scheme 1). Regulation of transcription and gene expression, including ARE/Nrf2, has been found to play a significant role in the effect of phytonutrients in many cellular processes [57]. As was found in the current study, carotenoids were shown to activate ARE/Nrf2 [26,28]. This transcription system can also be activated by polyphenols such as carnosic acid [58]. ARE/Nrf2 transcriptional activity is also activated by increased ROS levels, in order to lessen oxidative stress [19,59] (Scheme 1). Notably, in our study, the application of the phytonutrients and estradiol during oxidative stress increased ARE/Nrf2 activity to a level that was higher than that of the compounds or $\mathrm{H}_{2} \mathrm{O}_{2}$ alone. Similar to the activation of ARE/Nrf2 and the reduction in ROS in dermal fibroblasts described in the current study, estradiol activated ARE/Nrf2 and decreased ROS levels in neuronal cells, leading to cell survival and attenuation of homocysteine cytotoxicity [25]. In addition, estradiol can increase the expression of antioxidant enzymes by binding of estrogen receptor $\beta$ to an estrogen response element within the promoter region of antioxidant enzymes [60] (Scheme 1). An additional mechanism for the antioxidant effect of estradiol was suggested by Borrás et al. [61], who demonstrated that estradiol decreases hydrogen peroxide in isolated hepatic mitochondria, probably via interaction with specific receptors present in the mitochondria. Several publications suggest that the antioxidant effects of estradiol and other estrogens is mediated by direct chemical scavenging of ROS and not by the estrogen receptors [62]. This potential mechanism is controversial because scavenging of ROS occurs only at high, non-physiological estrogen concentrations. For example, $1 \mu \mathrm{M}$ estradiol was required to inhibit superoxide radical production by bovine heart endothelial cells, and about $50 \mu \mathrm{M}$ was used to inhibit lipid and low-density lipoprotein peroxidation in non-cellular experimental systems [63]. Lower estradiol concentrations $(100 \mathrm{nM})$ were used to reduce ROS formation in Friedreich's ataxia skin fibroblasts [62], a concentration that is ten times higher than the $10 \mathrm{nM}$ estradiol used in the current study. Moreover, in the experimental protocol used in the current study, direct interaction between estradiol and ROS was possible only in the oxidative stress phase of the experiments, when $\mathrm{H}_{2} \mathrm{O}_{2}$ and estradiol were both present. However, as shown in Figure 6, the protective effect of estradiol (and the phytonutrients) depends on the pre-incubation phase, when $\mathrm{H}_{2} \mathrm{O}_{2}$ is not present. These results suggest that the interaction between $\mathrm{H}_{2} \mathrm{O}_{2}$ and estradiol probably did not occur in the current experimental protocol. Based on these considerations, it is concluded that activation of defense mechanisms during the pre-incubation phase probably explains the protective effects of estradiol and the phytonutrients in oxidative stress-challenged dermal fibroblasts. Activation of ARE/Nrf2, which was demonstrated in the current study, and inhibition of several signaling pathways such as MAPKs, NFkB, and AP-1, are possibly involved in the protection of dermal fibroblasts.

\section{Conclusions}

This study indicates that carotenoids, polyphenols, and estradiol protect dermal fibroblasts from ROS-induced damage and suggests that a balanced diet rich in phytonutrients may improve skin health and appearance. In addition, improvement in skin health can be achieved by topical application of estradiol and crude or purified dietary compounds. Oxidative stress can result from numerous environmental factors, and also occurs during ageing. Because this stress may negatively affect many human tissues, the implications 
of this study may also be relevant to various other pathologies such as inflammation, neurodegenerative and cardiovascular diseases, and cancer.

Author Contributions: Conceptualization: A.D., J.L. and Y.S.; methodology: A.D. and A.T.; formal analysis: A.D. and A.T.; investigation: A.D.; writing-original draft preparation: A.D. and Y.S.; writing-review and editing: A.D., A.T. and Y.S.; visualization: A.D., A.T. and Y.S.; supervision: J.L. and Y.S.; project administration: J.L. and Y.S.; funding acquisition: J.L. and Y.S. All authors have read and agreed to the published version of the manuscript.

Funding: This research was funded by Lycored Ltd., Beer Sheva, Israel (to Y.S. and J.L.), grant numbers 87717111 and 87784411 .

Institutional Review Board Statement: Not applicable.

Informed Consent Statement: Not applicable.

Data Availability Statement: Data is contained within the article.

Acknowledgments: We thank M. Hannink (University of Missouri-Columbia, Columbia, MO, USA) for donating the 4xARE reporter construct used in this study and Robin Miller for English editing.

Conflicts of Interest: J.L. and Y.S. are consultants for Lycored Ltd., Beer Sheva, Israel. J.L. and Y.S. received research funding from Lycored. All other authors declare no conflicts of interest. Lycored is a supplier to the dietary supplement and functional food industries worldwide. Lycored Ltd. had no role in the design of the study; in the collection, analyses, or interpretation of data; in the writing of the manuscript, or in the decision to publish the results.

\section{References}

1. Bickers, D.R.; Athar, M. Oxidative Stress in the Pathogenesis of Skin Disease. J. Investig. Dermatol. 2006, 126, 2565-2575. [CrossRef]

2. Valacchi, G.; Sticozzi, C.; Pecorelli, A.; Cervellati, F.; Cervellati, C.; Maioli, E. Cutaneous responses to environmental stressors. Ann. N. Y. Acad. Sci. 2012, 1271, 75-81. [CrossRef]

3. Lephart, E.D. Skin aging and oxidative stress: Equol's anti-aging effects via biochemical and molecular mechanisms. Ageing Res. Rev. 2016, 31, 36-54. [CrossRef]

4. Betteridge, D.J. What is oxidative stress? Metabolism 2000, 49, 3-8. [CrossRef]

5. Pizzino, G.; Irrera, N.; Cucinotta, M.; Pallio, G.; Mannino, F.; Arcoraci, V.; Squadrito, F.; Altavilla, D.; Bitto, A. Oxidative Stress: Harms and Benefits for Human Health. Oxid. Med. Cell. Longev. 2017, 2017, 8416763. [CrossRef]

6. Chen, K.; Lu, P.; Beeraka, N.M.; Sukocheva, O.A.; Madhunapantula, S.V.; Liu, J.; Sinelnikov, M.Y.; Nikolenko, V.N.; Bulygin, K.V.; Mikhaleva, L.M.; et al. Mitochondrial mutations and mitoepigenetics: Focus on regulation of oxidative stress-induced responses in breast cancers. Semin. Cancer Biol. 2020. [CrossRef] [PubMed]

7. Fang, C.; Gu, L.; Smerin, D.; Mao, S.; Xiong, X. The Interrelation between Reactive Oxygen Species and Autophagy in Neurological Disorders. Oxid. Med. Cell. Longev. 2017, 2017, 8495160. [CrossRef]

8. Panth, N.; Paudel, K.R.; Parajuli, K. Reactive Oxygen Species: A Key Hallmark of Cardiovascular Disease. Adv. Med. 2016, 2016, 9152732. [CrossRef]

9. Redza-Dutordoir, M.; Averill-Bates, D.A. Activation of apoptosis signalling pathways by reactive oxygen species. Biochim. Biophys. Acta (BBA)-Mol. Cell Res. 2016, 1863, 2977-2992. [CrossRef] [PubMed]

10. Zhou, B.-R.; Yin, H.-B.; Xu, Y.; Wu, D.; Zhang, Z.-H.; Yin, Z.-Q.; Permatasari, F.; Luo, D. Baicalin protects human skin fibroblasts from ultraviolet A radiation-induced oxidative damage and apoptosis. Free Radic. Res. 2012, 46, 1458-1471. [CrossRef] [PubMed]

11. Rinnerthaler, M.; Bischof, J.; Streubel, M.K.; Trost, A.; Richter, K. Oxidative Stress in Aging Human Skin. Biomolecules 2015, 5, 545-589. [CrossRef]

12. Wang, L.; Lee, W.; Jayawardena, T.U.; Cha, S.H.; Jeon, Y.J. Dieckol, an algae-derived phenolic compound, suppresses airborne particulate matter-induced skin aging by inhibiting the expressions of pro-inflammatory cytokines and matrix metalloproteinases through regulating NF-kB, AP-1, and MAPKs signaling pathways. Food Chem. Toxicol. 2020, 146, 111823. [CrossRef] [PubMed]

13. Varani, J.; Spearman, D.; Perone, P.; Fligiel, S.E.; Datta, S.C.; Wang, Z.Q.; Shao, Y.; Kang, S.; Fisher, G.J.; Voorhees, J.J. Inhibition of type I procollagen synthesis by damaged collagen in photoaged skin and by collagenase-degraded collagen in vitro. Am. J. Pathol. 2001, 158, 931-942. [CrossRef]

14. Fam, V.W.; Charoenwoodhipong, P.; Sivamani, R.K.; Holt, R.R.; Keen, C.L.; Hackman, R.M. Plant-Based Foods for Skin Health: A Narrative Review. J. Acad. Nutr. Diet. 2021, in press. [CrossRef] [PubMed]

15. Michalak, M.; Pierzak, M.; Kręcisz, B.; Suliga, E. Bioactive Compounds for Skin Health: A Review. Nutrients 2021, 13, 203. [CrossRef]

16. Sies, H.; Stahl, W. Nutritional protection against skin damage from sunlight. Annu. Rev. Nutr. 2004, 24, 173-200. [CrossRef]

17. Heo, H.; Lee, H.; Yang, J.; Sung, J.; Kim, Y.; Jeong, H.S.; Lee, J. Protective Activity and Underlying Mechanism of Ginseng Seeds against UVB-Induced Damage in Human Fibroblasts. Antioxidants 2021, 10, 403. [CrossRef] 
18. Savoia, P.; Raina, G.; Camillo, L.; Farruggio, S.; Mary, D.; Veronese, F.; Graziola, F.; Zavattaro, E.; Tiberio, R.; Grossini, E. Anti-oxidative effects of $17 \beta$-estradiol and genistein in human skin fibroblasts and keratinocytes. J. Dermatol. Sci. 2018, 92, 62-77. [CrossRef] [PubMed]

19. Park, C.; Lee, H.; Noh, J.S.; Jin, C.-Y.; Kim, G.-Y.; Hyun, J.W.; Leem, S.-H.; Choi, Y.H. Hemistepsin A protects human keratinocytes against hydrogen peroxide-induced oxidative stress through activation of the Nrf2/HO-1 signaling pathway. Arch. Biochem. Biophys. 2020, 691, 108512. [CrossRef]

20. Abu Zaid, M.; Afaq, F.; Syed, D.N.; Dreher, M.; Mukhtar, H. Inhibition of UVB-mediated oxidative stress and markers of photoaging in immortalized HaCaT keratinocytes by pomegranate polyphenol extract POMx. Photochem. Photobiol. 2007, 83, 882-888. [CrossRef]

21. Calniquer, G.; Khanin, M.; Ovadia, H.; Linnewiel-Hermoni, K.; Stepensky, D.; Trachtenberg, A.; Sedlov, T.; Braverman, O.; Levy, J.; Sharoni, Y. Combined Effects of Carotenoids and Polyphenols in Balancing the Response of Skin Cells to UV Irradiation. Molecules 2021, 26, 1931. [CrossRef]

22. Lim, S.-R.; Kim, D.-W.; Sung, J.; Kim, T.H.; Choi, C.-H.; Lee, S.-J. Astaxanthin Inhibits Autophagic Cell Death Induced by Bisphenol A in Human Dermal Fibroblasts. Antioxidants 2021, 10, 1273. [CrossRef] [PubMed]

23. Afaq, F.; Zaid, M.A.; Khan, N.; Dreher, M.; Mukhtar, H. Protective effect of pomegranate-derived products on UVB-mediated damage in human reconstituted skin. Exp. Dermatol. 2009, 18, 553-561. [CrossRef]

24. Lephart, E.D. A review of the role of estrogen in dermal aging and facial attractiveness in women. J. Cosmet. Dermatol. 2018, 17, 282-288. [CrossRef] [PubMed]

25. Chen, C.S.; Tseng, Y.T.; Hsu, Y.Y.; Lo, Y.C. Nrf2-Keap1 Antioxidant Defense and Cell Survival Signaling Are Upregulated by 17 $\beta$-Estradiol in Homocysteine-Treated Dopaminergic SH-SY5Y Cells. Neuroendocrinology 2013, 97, 232-241. [CrossRef] [PubMed]

26. Ben-Dor, A.; Steiner, M.; Gheber, L.; Danilenko, M.; Dubi, N.; Linnewiel, K.; Zick, A.; Sharoni, Y.; Levy, J. Carotenoids activate the antioxidant response element transcription system. Mol. Cancer 2005, 4, 177-186.

27. Zhou, Y.; Jiang, Z.; Lu, H.; Xu, Z.; Tong, R.; Shi, J.; Jia, G. Recent Advances of Natural Polyphenols Activators for Keap1-Nrf2 Signaling Pathway. Chem. Biodivers. 2019, 16, e1900400. [CrossRef]

28. Linnewiel, K.; Ernst, H.; Caris-Veyrat, C.; Ben-Dor, A.; Kampf, A.; Salman, H.; Danilenko, M.; Levy, J.; Sharoni, Y. Structure activity relationship of carotenoid derivatives in activation of the electrophile/antioxidant response element transcription system. Free Radic. Biol. Med. 2009, 47, 659-667. [CrossRef]

29. Cooney, R.V.; Joseph Kappock, T.; Pung, A.; Bertram, J.S. Solubilization, cellular uptake, and activity of $\beta$-carotene and other carotenoids as inhibitors of neoplastic transformation in cultured cells. In Methods in Enzymology; Academic Press: Cambridge, MA, USA, 1993; Volume 214, pp. 55-68.

30. Levy, J.; Bosin, E.; Feldman, B.; Giat, Y.; Miinster, A.; Danilenko, M.; Sharoni, Y. Lycopene is a more potent inhibitor of human cancer cell proliferation than either alpha-carotene or beta-carotene. Nutr. Cancer 1995, 24, 257-266. [CrossRef]

31. Pesakhov, S.; Nachliely, M.; Barvish, Z.; Aqaqe, N.; Schwartzman, B.; Voronov, E.; Sharoni, Y.; Studzinski, G.P.; Fishman, D.; Danilenko, M. Cancer-selective cytotoxic $\mathrm{Ca}^{2+}$ overload in acute myeloid leukemia cells and attenuation of disease progression in mice by synergistically acting polyphenols curcumin and carnosic acid. Oncotarget 2016, 7, 31847-31861. [CrossRef]

32. Cullinan, S.B.; Zhang, D.; Hannink, M.; Arvisais, E.; Kaufman, R.J.; Diehl, J.A. Nrf2 is a direct PERK substrate and effector of PERK-dependent cell survival. Mol. Cell. Biol. 2003, 23, 7198-7209. [CrossRef]

33. Takasawa, R.; Nakamura, H.; Mori, T.; Tanuma, S. Differential apoptotic pathways in human keratinocyte HaCaT cells exposed to UVB and UVC. Apoptosis 2005, 10, 1121-1130. [CrossRef] [PubMed]

34. Pongcharoen, S.; Warnnissorn, P.; Lertkajornsin, O.; Limpeanchob, N.; Sutheerawattananonda, M. Protective effect of silk lutein on ultraviolet B-irradiated human keratinocytes. Biol. Res. 2013, 46, 39-45. [CrossRef]

35. Yoshihisa, Y.; Rehman, M.u.; Shimizu, T. Astaxanthin, a xanthophyll carotenoid, inhibits ultraviolet-induced apoptosis in keratinocytes. Exp. Dermatol. 2014, 23, 178-183. [CrossRef]

36. Fazekas, Z.; Gao, D.; Saladi, R.N.; Lu, Y.; Lebwohl, M.; Wei, H. Protective effects of lycopene against ultraviolet B-induced photodamage. Nutr. Cancer 2003, 47, 181-187. [CrossRef] [PubMed]

37. Giampieri, F.; Alvarez-Suarez, J.M.; Mazzoni, L.; Forbes-Hernandez, T.Y.; Gasparrini, M.; Gonzàlez-Paramàs, A.M.; Santos-Buelga, C.; Quiles, J.L.; Bompadre, S.; Mezzetti, B.; et al. Polyphenol-Rich Strawberry Extract Protects Human Dermal Fibroblasts against Hydrogen Peroxide Oxidative Damage and Improves Mitochondrial Functionality. Molecules 2014, 19, 7798-7816. [CrossRef]

38. Afaq, F.; Syed, D.N.; Malik, A.; Hadi, N.; Sarfaraz, S.; Kweon, M.H.; Khan, N.; Zaid, M.A.; Mukhtar, H. Delphinidin, an anthocyanidin in pigmented fruits and vegetables, protects human HaCaT keratinocytes and mouse skin against UVB-mediated oxidative stress and apoptosis. J. Invest. Dermatol. 2007, 127, 222-232. [CrossRef]

39. Li, L.-H.; Wu, L.-J.; Tashiro, S.-i.; Onodera, S.; Uchiumi, F.; Ikejima, T. Silibinin Prevents UV-Induced HaCaT Cell Apoptosis Partly through Inhibition of Caspase-8 Pathway. Biol. Pharm. Bull. 2006, 29, 1096-1101. [CrossRef] [PubMed]

40. Pérez-Sánchez, A.; Barrajón-Catalán, E.; Caturla, N.; Castillo, J.; Benavente-García, O.; Alcaraz, M.; Micol, V. Protective effects of citrus and rosemary extracts on UV-induced damage in skin cell model and human volunteers. J. Photochem. Photobiol. B 2014, 136, 12-18. [CrossRef]

41. Shin, S.W.; Jung, E.; Kim, S.; Lee, K.-E.; Youm, J.-K.; Park, D. Antagonist Effects of Veratric Acid against UVB-Induced Cell Damages. Molecules 2013, 18, 5405-5419. [CrossRef] 
42. Park, J.-H.; Shin, J.-M.; Yang, H.-W.; Kim, T.H.; Lee, S.H.; Lee, H.-M.; Cho, J.-G.; Park, I.-H. Cigarette Smoke Extract Stimulates MMP-2 Production in Nasal Fibroblasts via ROS/PI3K, Akt, and NF-kB Signaling Pathways. Antioxidants 2020, 9, 739. [CrossRef] [PubMed]

43. Yi, R.; Zhang, J.; Sun, P.; Qian, Y.; Zhao, X. Protective Effects of Kuding Tea (Ilex kudingcha C. J. Tseng) Polyphenols on UVB-Induced Skin Aging in SKH1 Hairless Mice. Molecules 2019, 24, 1016. [CrossRef] [PubMed]

44. Yamawaki, Y.; Mizutani, T.; Okano, Y.; Masaki, H. Xanthophyll Carotenoids Reduce the Dysfunction of Dermal Fibroblasts to Reconstruct the Dermal Matrix Damaged by Carbonylated Proteins. J. Oleo Sci. 2021, 70, 647-655. [CrossRef]

45. Grether-Beck, S.; Marini, A.; Jaenicke, T.; Stahl, W.; Krutmann, J. Molecular evidence that oral supplementation with lycopene or lutein protects human skin against ultraviolet radiation: Results from a double-blinded, placebo-controlled, crossover study. $\mathrm{Br}$. $\mathrm{J}$. Dermatol. 2017, 176, 1231-1240. [CrossRef]

46. Rizwan, M.; Rodriguez-Blanco, I.; Harbottle, A.; Birch-Machin, M.A.; Watson, R.E.; Rhodes, L.E. Tomato paste rich in lycopene protects against cutaneous photodamage in humans in vivo: A randomized controlled trial. Br. J. Dermatol. 2011, 164, 154-162. [CrossRef] [PubMed]

47. Son, E.D.; Lee, J.Y.; Lee, S.; Kim, M.S.; Lee, B.G.; Chang, I.S.; Chung, J.H. Topical application of 17 beta-estradiol increases extracellular matrix protein synthesis by stimulating tgf-Beta signaling in aged human skin in vivo. J. Invest. Dermatol. 2005, 124, 1149-1161. [CrossRef]

48. Liu, S.; Yang, S.-D.; Huo, X.-W.; Yang, D.-L.; Ma, L.; Ding, W.-Y. 17ß-Estradiol inhibits intervertebral disc degeneration by down-regulating MMP-3 and MMP-13 and up-regulating type II collagen in a rat model. Artif. Cells Nanomed. Biotechnol. 2018, 46, 182-191. [CrossRef]

49. Bosch, R.; Philips, N.; Suarez-Perez, J.A.; Juarranz, A.; Devmurari, A.; Chalensouk-Khaosaat, J.; Gonzalez, S. Mechanisms of Photoaging and Cutaneous Photocarcinogenesis, and Photoprotective Strategies with Phytochemicals. Antioxidants 2015, 4, 248-268. [CrossRef]

50. Debacq-Chainiaux, F.; Leduc, C.; Verbeke, A.; Toussaint, O. UV, stress and aging. Dermato-Endocrinology 2012, 4, 236-240. [CrossRef]

51. Karthikeyan, R.; Kanimozhi, G.; Prasad, N.R.; Agilan, B.; Ganesan, M.; Mohana, S.; Srithar, G. 7-Hydroxycoumarin prevents UVB-induced activation of NF- $\mathrm{KB}$ and subsequent overexpression of matrix metalloproteinases and inflammatory markers in human dermal fibroblast cells. J. Photochem. Photobiol. B Biol. 2016, 161, 170-176. [CrossRef]

52. Linnewiel-Hermoni, K.; Motro, Y.; Miller, Y.; Levy, J.; Sharoni, Y. Carotenoid derivatives inhibit nuclear factor kappa B activity in bone and cancer cells by targeting key thiol groups. Free Radic. Biol. Med. 2014, 75, 105-120. [CrossRef]

53. Guruvayoorappan, C.; Kuttan, G. $\beta$-Carotene Inhibits Tumor-Specific Angiogenesis by Altering the Cytokine Profile and Inhibits the Nuclear Translocation of Transcription Factors in B16F-10 Melanoma Cells. Integr. Cancer Ther. 2007, 6, 258-270. [CrossRef]

54. Izumi-Nagai, K.; Nagai, N.; Ohgami, K.; Satofuka, S.; Ozawa, Y.; Tsubota, K.; Umezawa, K.; Ohno, S.; Oike, Y.; Ishida, S. Macular pigment lutein is antiinflammatory in preventing choroidal neovascularization. Arter. Thromb. Vasc. Biol. 2007, 27, 2555-2562 [CrossRef] [PubMed]

55. Kundu, J.K.; Shin, Y.K.; Kim, S.H.; Surh, Y.-J. Resveratrol inhibits phorbol ester-induced expression of COX-2 and activation of NF- $\kappa B$ in mouse skin by blocking IкB kinase activity. Carcinogenesis 2006, 27, 1465-1474. [CrossRef] [PubMed]

56. McMurray, R.W.; Ndebele, K.; Hardy, K.J.; Jenkins, J.K. 17- $\beta$-estradiol suppresses IL-2 and IL-2 receptor. Cytokine 2001, 14, 324-333. [CrossRef]

57. Sharoni, Y.; Linnewiel-Hermoni, K.; Zango, G.; Khanin, M.; Salman, H.; Veprik, A.; Danilenko, M.; Levy, J. The role of lycopene and its derivatives in the regulation of transcription systems: Implications for cancer prevention. Am. J. Clin. Nutr. 2012, 96, 1173S-1178S. [CrossRef]

58. Kosaka, K.; Mimura, J.; Itoh, K.; Satoh, T.; Shimojo, Y.; Kitajima, C.; Maruyama, A.; Yamamoto, M.; Shirasawa, T. Role of Nrf2 and p62/ZIP in the neurite outgrowth by carnosic acid in PC12h cells. J. Biochem. 2009, 147, 73-81. [CrossRef] [PubMed]

59. Itoh, K.; Tong, K.I.; Yamamoto, M. Molecular mechanism activating Nrf2-Keap1 pathway in regulation of adaptive response to electrophiles. Free Radic. Biol. Med. 2004, 36, 1208-1213. [CrossRef]

60. Jackson, R.L.; Greiwe, J.S.; Schwen, R.J. Ageing skin: Oestrogen receptor $\beta$ agonists offer an approach to change the outcome. Exp. Dermatol. 2011, 20, 879-882. [CrossRef]

61. Borrás, C.; Gambini, J.; López-Grueso, R.; Pallardó, F.V.; Viña, J. Direct antioxidant and protective effect of estradiol on isolated mitochondria. Biochim. Biophys. Acta 2010, 1802, 205-211. [CrossRef]

62. Richardson, T.E.; Yang, S.H.; Wen, Y.; Simpkins, J.W. Estrogen protection in Friedreich's ataxia skin fibroblasts. Endocrinology 2011, 152, 2742-2749. [CrossRef] [PubMed]

63. Ayres, S.; Abplanalp, W.; Liu, J.H.; Subbiah, M.T.R. Mechanisms involved in the protective effect of estradiol-17 $\beta$ on lipid peroxidation and DNA damage. Am. J. Physiol.-Endocrinol. Metab. 1998, 274, E1002-E1008. [CrossRef] [PubMed] 